\title{
Biosequence stratigraphical and palaeoenvironmental findings from the Cretaceous through Tertiary succession, Central Indus Basin, Pakistan
}

\author{
M. I. WAKEFIELD ${ }^{1} \&$ E. MONTEIL ${ }^{1,2}$ \\ ${ }^{1}$ BG Group, 100 Thames Valley Park Drive, Reading RG6 1PT, UK \\ ${ }^{2}$ Geoscience Australia, GPO Box 378, Canberra, ACT 2601, Australia
}

\begin{abstract}
Integrated analysis of foraminiferal and palynological data from the Duljan-1 well, Central Indus Basin, Pakistan, is used to identify critical surfaces (candidate sequence boundaries (SB) and maximum flooding surfaces (MFS)) and construct a biosequence stratigraphical framework. Within the Barremian through Bartonian-Priabonian? succession 15 depositional sequences have been recognized, each with a candidate MFS. These biosequences are shown to equate with the local lithostratigraphy and tentatively with the 'global' large-scale depositional cycles of Haq et al. (1987). Detailed dating has enabled seven candidate MFS to be tentatively equated with MFS identified on the nearby Arabian plate (Sharland et al., 2001). A combination of detailed age dating and palaeobathymetric determinations indicates significant basin uplift and erosion at end Cretaceous and end Eocene times, the latter coinciding with closure of Neo-Tethys. Smaller-scale unconformities are also noted. Multi-disciplinary palaeoenvironmental interpretations enable recognition of detailed changes in water mass conditions. Palynological data suggest these changes result from variations in terrestrial/freshwater input, though evidence of periodically low oxygen bottom water conditions/shallowing of the oxygen minimum zone, possibly 'Oceanic Anoxic Event-2' (OAE-2; late Cenomanian-Turonian) is suggested as a further control. J. Micropalaeontol. 21(2): 115-130, December 2002.
\end{abstract}

\section{LOCATION OF STUDY WELL}

This study is based on the investigation of foraminiferal, nannofossil and palynological data from the Duljan-1 well situated between the central and lower portions of the Indus Basin (Fig. 1). The central and lower basins are constrained by the Mari-Khandkot-Jaisalmer High to the east, the Kirthar Foldbelt and Foredeep to the west (Fig. 1), while the Jacobabad High is sometimes used to separate the lower and central basins (e.g. Kemal et al., 1992), with the upper basin north of the Sargodha High. During the Cretaceous, deposition of the Duljan-1 succession occurred close to the palaeo-shelf slope break between the Talhar Terrace and Thar Slope. The area has a complex geological history, where relative sea-level was controlled both eustatically and by local/basinal tectonics.

The Geological Survey of India initially developed the lithostratigraphical nomenclature of the Indus Basin (Blanford, 1879). This basic framework has been refined following measurement of outcrop sections and data from hydrocarbon exploration of the basin (Eames, 1952; Williams, 1959; Hemphill \& Kidwai, 1973; Ahmed et al., 1977; Kemal et al., 1992). The Tertiary lithostratigraphy from the nearby Sulaiman Range (Fig. 1) has been shown to equate to depositional sequences (Jones, 1997).

\section{DATA}

The data interpreted herein were generated as follows; palynology (183 ditch cuttings and 11 sidewall cores) by Jeffery Goodall, Ichron Limited; Foraminifera (176 ditch cuttings, seven sidewall cores and nine thin sections) by Deryck D. Bayliss; nannofossils (16 ditch cuttings and two sidewall cores) by Liam Gallagher and Matt Hampton, Network Stratigraphic Consulting Limited. The nannofossil data were used solely to refine chronostratigraphical determinations. That the dominant source of biostratigraphical data was from ditch cuttings means

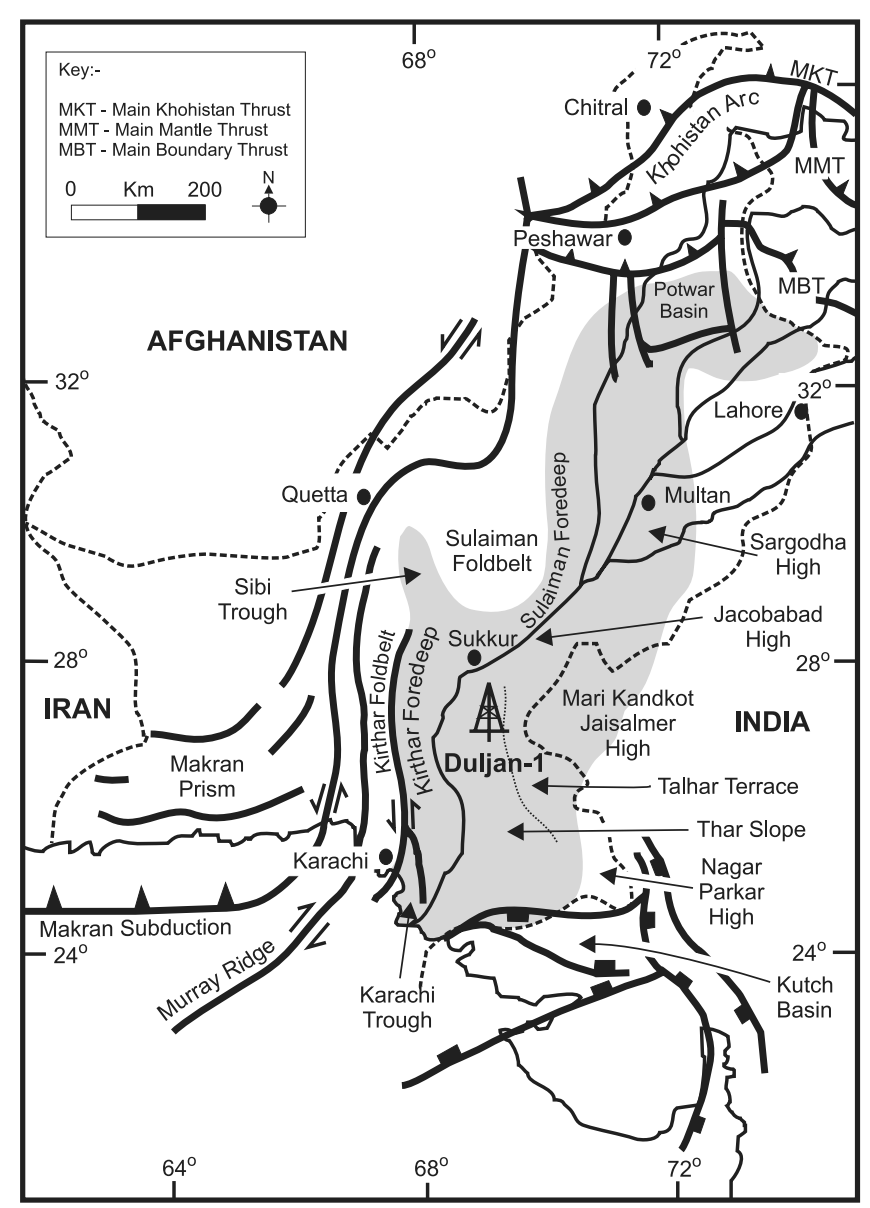

Fig. 1. Location map of Pakistan showing position of Indus Basin (shaded), major structural fabric and position of Duljan-1 well. 
that data are likely influenced by temporal and ecological smearing. Therefore, any depths quoted are given as the basal depth of the ditch cuttings interval that represents 6-10 m. Any specimens recognized (age context, preservation) as being reworked or caved were removed from the dataset prior to any palaeoenvironmental analyses being undertaken.

\section{BIOSTRATIGRAPHICAL IDENTIFICATION OF SEQUENCE STRATIGRAPHICAL SURFACES}

The applied use of quantitative biostratigraphy in allostratigrapical studies has been demonstrated at basin and reservoir scales (e.g. Armentrout (1987, 1996), Armentrout \& Clement (1990), Armentrout et al. (1990), Mitchum et al. (1993), Shaffer (1987)) and, more recently, by Sharland et al. (2001). A general summary of the applied use of biostratigraphy is given by Emery \& Myers (1996). Several basic biostratigraphical signals have been associated with critical stratigraphical surfaces, i.e. SB and MFS. These include palaeobathymetry derived from detailed knowledge of benthonic foraminiferal bathymetric ranges, abundance variation of foraminifera, the planktonic:benthonic foraminiferal ratio (P:B), abundance variation of nannofossils and fluctuations in simple species diversity. Shaffer (1987) showed that reduced specimen abundance and simple species diversity of nannofossils equated to a SB, while the MFS was characterized by high specimen abundance and high simple species diversity. A similar pattern is seen with foraminiferal data, while parasequence-scale cyclicity is probably reflected by smaller-scale fluctuations of specimen abundance and diversity. Such variations, ignoring the effects of taphonomy, sample quality and spacing, positively correlate with sediment accumulation rate. The interpretation of abundance peaks is not simple, however, as upwelling nutrient-rich waters also produce intervals of abundant planktonic fossils (Simmons \& Williams, 1992).

Biostratigraphically determined critical surfaces do not always coincide with those identified using well logs, in most cases due to different sampling intervals, e.g. $30 \mathrm{~cm}$ for well $\operatorname{logs}$ and 6-10 $\mathrm{m}$ for the ditch cuttings from Duljan-1. Palaeontologically, the MFS is located at the point of greatest palaeobathymetry, whereas Baum \& Vail (1988), Loutit et al. (1988) and Posamentier et al. (1988) position the MFS at the point of maximum shoreline transgression, which does not necessarily equate to the greatest water depth. However, maximum palaeobathymetry and the point of maximum shoreline transgression are likely to be stratigraphically irresolvable using cuttings samples. The points of shallowest palaeobathymetry were similarly characterized using the generally low numbers of foraminifera, planktonic taxa in particular (Armentrout \& Clement, 1990).

\section{PALAEONTOLOGICAL DETERMINATION OF PALAEOBATHYMETRY}

Palaeobathymetry was calculated using the 'Integrated Paleontological System' (IPS) software. IPS uses a depth framework of eight zones (Table 1) based on the modification by Culver (1988) of Albers et al. (1966) foraminiferal-based bathymetric subdivision of the Gulf of Mexico. Each benthonic

\begin{tabular}{lcc}
\hline Bathymetric zone & Depth $(\mathrm{m})$ & Depth $(\mathrm{ft})$ \\
\hline Transitional coastal/paralic & & \\
Inner Neritic & $0-20$ & $0-60$ \\
Middle Neritic & $20-100$ & $60-300$ \\
Outer Neritic & $100-200$ & $300-600$ \\
Upper Bathyal & $200-500$ & $600-1500$ \\
Middle Bathyal & $500-1000$ & $1500-3000$ \\
Lower Bathyal & $1000-2000$ & $3000-6000$ \\
Abyssal & $2000+$ & $6000+$ \\
\hline
\end{tabular}

Table 1. IPS bathymetry zones.

foraminiferal species in a sample is cross-referenced against an in-house database of $c .7000$ species with their water-depth limits. Bathymetric ranges of Recent taxa are readily available (e.g. Culver (1988) and Picou et al. (1999)) and can be used with confidence. Substantive uniformitarianism is used throughout the Tertiary to define palaeobathymetric ranges of benthonic foraminifera (e.g. Charnock \& Jones, 1990), which can be used with some confidence. However, palaeobathymetric ranges of Cretaceous taxa, often obtained from basin modeling (e.g. Nyong \& Olsson (1984), Olsson \& Nyong (1984) and Olsson (1988)), are treated with some caution. Therefore additional evidence is required to confirm bathymetric trends. Using a weighted average of upper depth limits, an 'average palaeobathymetry' based on all taxa present in a sample matching the database is calculated. Empirical analysis of modern Gulf of Mexico box core samples indicates that the bulk of the benthonic foraminiferal population for a given species begins about one standard deviation deeper than its upper depth limit (A. Gary pers. comm., 2000). Therefore, IPS appends a fraction of the standard deviation of the 'average palaeobathymetry' producing a shift toward deeper water termed the 'bathymetric best estimate' (see Fig. 2). IPS also indicates if taxa in a sample have upper depth limits deeper than the 'bathymetric best estimate' (Fig. 2).

The $\mathrm{P}: \mathrm{B}$ ratio is defined as the number of planktonic foraminifera relative to the total benthonic foraminifera (calcareous and agglutinating). Modern data and geological evidence show that the $\mathrm{P}: \mathrm{B}$ ratio positively correlates with increasing water depth and distance from shore but can be modified by down slope transport (Gibson, 1989). The P:B ratio decreases as salinity decreases (Funnel, 1967). Abundant planktonic assemblages are interpreted as being indicative of relatively highstand sea-levels, an apparently simple relationship but not an absolute rule. Hayward (1986) attributed high P:B ratios in intertidal sediments to current and wave transport. Conversely, low P:B ratios may sometimes give a false shallow-water depth estimate, as planktonic foraminifera are generally more susceptible to dissolution than are benthonic foraminifera. In particular acidic/low oxygen bottom waters, sometimes associated with the MFS, may lead to high levels of dissolution. Planktonic and calcareous benthonic foraminifera are progressively dissolved in sediments occurring beneath the oceanic lysocline/Carbonate Compensation Depth. Thin-walled Globigerinoides and Globigerina dissolve before thicker-walled Globorotalia, Pulleniatina and Sphaeroidinella. Numbers of planktonic foraminifera may show apparent reduction due to high depositional rates (sediment dilution), e.g. lowstand fans. Therefore, the P:B ratio 


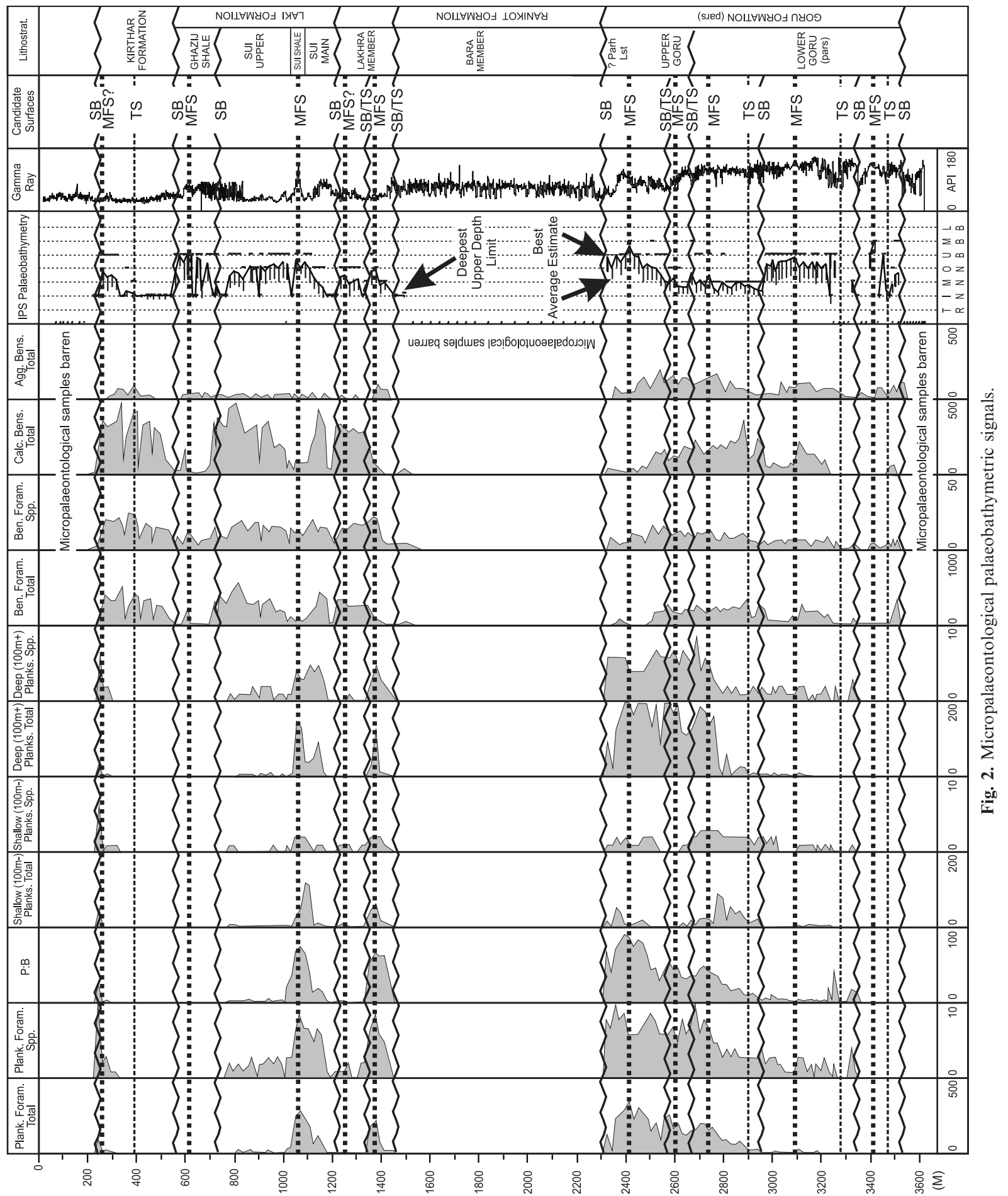


should only be used as a secondary criterion for determining palaeobathymetry.

Planktonic foraminifera live at various depths within the water column (Be, 1977; Hart \& Bailey, 1979; Hart, 1980). Planktonic foraminifera from Duljan-1 were divided into two groups; a shallow-water group living in the top $50 \mathrm{~m}$ of the water column (e.g. Subbotina and Globigerinelloides) and a group living deeper in the water column (e.g. Rotalipora and Ticinella), providing a low resolution qualitative assessment of palaeobathymetry.

Palynomorphs are used to measure relative distance from shore, the relationship to water depth being implied rather than measured. Dinocyst diversity increases from near shore to offshore as dominance decreases (Tyson, 1995). Phytoplankton diversity tends to decrease in areas with low salinity while dominance and density increase (Smayda, 1983). Unstable near-shore environments or upwelling areas tend to be colonized by a small number of eurotypic dinocysts and show a similar pattern. More marine, more offshore and more transgressive facies typically show increasing dinocyst diversity and lower dominance and can therefore be a useful indicator of relative transgressive-regressive trends (Tyson, 1995).

Dinocyst morphogroups have similar utility to the general offshore abundance trend in dinocyst abundance. Peridinioiddominated assemblages are considered indicative of lagoonal, estuarine or brackish water environments. Gonyaulacoiddominated assemblages are characteristic of more open-marine facies (Downie et al., 1971; Köthe, 1990). Harland (1973) introduced the Gonyaulacacean:Peridinialean ratio (G:P; based on species number) as a guide to salinity fluctuations and shoreline proximity. Mao \& Mohr (1992) used the G:P ratio (based on specimen number) to help identify palaeoenvironmental changes. Bujak (1984) postulated that high relative abundance of Peridiniaceans indicated nutrient upwelling, while Powell et al. (1992) used P:G as a proxy for upwelling intensity and productivity. However, Eshet et al. (1994) observed that low ratios might be associated with bioturbation. The relative increase in skolochorate dinocysts offshore may be due to either functional morphology or variation in water temperature (see references in Tyson, 1995). The dinocyst morphological groupings used herein are given in Table 2.

In Recent shelf sediments from offshore South Africa the highest abundances of sporomorphs and dinocysts occur near shore and decrease gradually offshore (Davey, 1971; Davey \& Rogers, 1975). On the upper part of the continental slope both increase again; however, the dinocysts are 3-10 times more abundant than the sporomorphs. Sporomorphs decline more rapidly away from the shore than do dinocysts, indicating that the sporomorph:dinocyst ratio is meaningful as a shoreline indicator. According to Tyson (1995) the percentage of marine palynomorphs in pelagic sediments is often low, but it may be increased in turbidites due to redeposition of dinocysts from the continental shelf and slope. Frequently turbidites may contain abundant recycled dinocysts, but more commonly such deposits yield greater percentages of recycled sporomorphs transported over larger distances. The relative abundance of organic-walled microplankton indicative of marine conditions, i.e. dinocysts, acritarchs and prasinophycean algae, is inversely related to that

\begin{tabular}{|c|c|}
\hline Achilleodinium - A, G, Sk & Hystrichodinium - A, G, Sk \\
\hline Achomosphaera-A, G, Sk & Hystrichokolpoma-A, G, Sk \\
\hline Adnatosphaeridium - A, G, Sk & Hystrichosphaeridium - A, G, Sk \\
\hline Alterbidinium - Cv, P, Px & Impagidinium - A, G, PC \\
\hline Amphorosphaeridium - A, G, Sk & Impletosphaeridium - A, G, Sk \\
\hline Apectodinium - Cv, P, PC & Kallosphaeridium - A, G, Px \\
\hline Aptea $-\mathrm{A}, \mathrm{C}, \mathrm{Px}$ & Kiokansium - A, G, Sk \\
\hline Apteodinium - A, G, Px & Lanterna - A, G, PC \\
\hline Areoligera - A, G, Sk & Leberidocysta $-\mathrm{Cv}, \mathrm{P}, \mathrm{Px}$ \\
\hline Caligodinium - A, G, Px & Lejeunecysta - A, P, Px \\
\hline Canningia - A, G, Px & Litosphaeridium - A, G, Sk \\
\hline Canninginopsis - A, G, Px & Melitasphaeridium - A, G, Sk \\
\hline Cassiculosphaeridia - A, G, Px & Membranilarnacia - $\mathrm{Cv}, \mathrm{G}, \mathrm{Px}$ \\
\hline Саиса - A, G, Sk & Muderongia-Cv, C, Px \\
\hline Cerbia - A, G, Px & Nelchinopsis - A, G, PC \\
\hline Circulodinium - A, G, PC & Nematosphaeropsis - A, G, PC \\
\hline Cleistosphaeridium - A, G, Sk & Odontochitina $-\mathrm{Cv}, \mathrm{C}, \mathrm{Px}$ \\
\hline Cordosphaeridium - A, G, Sk & Oligosphaeridium - A, G, Sk \\
\hline Coronifera - A, G, Sk & Operculodinium - A, G, Sk \\
\hline Cribroperidinium - A, G, Px & Palaeohystrichophora- Cv, P, PC \\
\hline Cyclonephelium - A, G, PC & Palaeoperidinium - Cv, P, Px \\
\hline Dapsilidinium- A, G, Sk & Pervosphaeridium - A, G, Sk \\
\hline Dinopterygium - A, G, Px \& PC & Polysphaeridium - A, G, Sk \\
\hline Diphyes - A, G, Sk & Pseudoceratium - A, C, Px \& PC \\
\hline Dissiliodinium - A, G, Px & Pterodinium - A, G, PC \\
\hline Endoceratium - Cv, C, Px & Rhynchodiniopsis - A, G, PC \\
\hline Enneadocysta - A, G, Px & Senoniasphaera - Cv, G, Px \\
\hline Epelidosphaeridia-A, P, PC & Spiniferites - A, G, Sk \\
\hline Exochosphaeridium - A, G, Sk & Subtilisphaera $-\mathrm{Cv}, \mathrm{P}, \mathrm{Px} \& \mathrm{PC}$ \\
\hline Fibrocysta - A, G, Sk & Tanyosphaeridium - A, G, Sk \\
\hline Florentinia - A, G, Sk & Tectatodinium - A, G, Px \\
\hline Glaphyrocysta-A, G, Sk & Тепиа - A, G, PC \\
\hline Gonyaulacysta - A/C, G, Px & Thalassiphora- $\mathrm{Cv}, \mathrm{G}, \mathrm{Px}$ \\
\hline Hapsocysta-A, G & Trichodinium - A, G, PC \\
\hline Heslertonia - A, G, Ch & Xenascus - Cv, C, PC \\
\hline Homotryblium - A, G, Sk & Xiphophoridium - A, G, PC \\
\hline
\end{tabular}

A, Acavate; C, Ceratioid; Ch, Chorate; Cv, Cavate; G, Gonyaulacoid; P, Peridinioid; PC, Proximochorate; Px, Proximate; Sk, Skolochorate.

Table 2. Morphological grouping of dinocyst genera applied herein.

of miospores indicative of terrestrial conditions (Tyson, 1995). The ratio of these elements is herein called the Marine Influence Index (MII). The so-called 'Neves effect' of Chaloner \& Muir (1968) describes the distribution given above and explains the relative enrichment of hinterland elements (bisaccate gymnosperms) in marine sediments by air or water transport. Therefore, the MII is calculated without bisaccates to remove any ambiguity.

Poumot (1989) and Morley (1991, 1996) defined the relative succession of palynofloras associated with systems tracts in Tertiary deltaic sediments. Those authors recognized that mangrove pollen is most abundant at the MFS and can be used as a proxy for salinity and sea-level fluctuations. Mangrove taxa are tolerant of salt and live in intertidal areas. Almost all modern coastlines between $25^{\circ} \mathrm{N} \& \mathrm{~S}$ of the equator are dominated by mangrove swamp ecosystems (see Plaziat, 1995 for a review). The Indus Basin lay within this latitudinal band throughout deposition of the Duljan-1 succession (Barremian through Bartonian-Priabonian?); see Enclosure 2b of Sharland et al. (2001). Therefore, fluctuations in abundance of mangrove pollen are used as a proxy for marine flooding events. Pollen and spore palaeoecological data used herein are summarized in Table 3 . 


\section{Hinterland}

Aequitriradites spinulosus - bisaccate

Aequitriradites verrucosus - bisaccate

Alnipollenites verus - Alnus ?; temperate climate or mountains in tropical areas

Araucariacidites australis - AraucarialPodozamites; conifer?

Callialosporites dampieri - conifer

Callialosporites trilobatus - conifer

Classopollis (clusters) - Cheirolepidiaceae; coastal in Mesozoic; semi-arid

Classopollis brasiliensis - Cheirolepidiaceae; coastal in Mesozoic; semi-arid

Classopollis torosus - Cheirolepidiaceae; coastal in Mesozoic; semi-arid

Compositioipollenites spp. - more common in savannah/higher montane than lowland forest

Ephedripites spp. - Ephedraceae; steppe alpine climate/semi-arid/2500-5500 m

Spheripollenites psilatus - Cheirolepidacean -Taxodiacean conifer

Rugubivesiculites multisaccus - bisaccate

Ferns \& lowland marsh (freshwater)

Arecipites spp. - tropical peat marshes

Baculatisporites comauensis - Osmundaceae; lowland marsh or river fern

Cicatricosisporites dorogensis - Schizeaecea; Pteridophyte, semi-arid tropical lowland marsh

Cicatricosisporites segmentatus - Schizeaecea; Pteridophyte, semi-arid tropical lowland marsh

Cicatricosisporites spp. - Schizeaecea; Pteridophyte, semi-arid tropical lowland marsh

Cicatricosisporites turbatus - Schizeaecea; Pteridophyte, semi-arid tropical lowland marsh

Cycadopites spp. - cycads

Deltoidospora hallei - coastal/beach fern

Gleicheniidites senonicus - Gleicheniaceaea; Pteridophyte, possibly a liana

Inaperturopellenites hiatus - Taxodiaceae; subtropical humid peat swamps

Laevigatosporites minor - Polypodiaceaea; Pteridophyte, possibly epiphytic

Laevigatosporites spp. - Polypodiaceaea; Pteridophyte, possibly epiphytic

Lagerstroemia spp. - fern swamp/sal forest $0-1000 \mathrm{~m}$

Lanagiopollis spp. - freshwater swamps

Liliacidites spp. - liana?, similar to modern Pseudophoenix sp.

Lycopodiaceoisporites annulatus

Lycopodiacidites carniidites - club mosses

Momipites spp. - Engelhardia complex (Alfordia, Oreomunnea) lowland peat swamps

Pandanus spp. - peat swamps

Polypodiaceoisporites spp. - Pteridaceae; tropical fern swamp

Polypodiisporonites afavus - tropical fern swamp

Polypodiisporonites haardti - tropical fern swamp

Schizea spp. - tropical fern swamp

Sestrosporites pseudoalveolatus (=Lycopodium manii, Lycopodium laterale)

Staplinisporites telatus - Lycopodiaceae; Pteridophyte

Stereisporites spp. - Sphagnaceae/Selaginellaceae?, Bryophyte?; swamp mosses

Striatricolpites catatumbus - tropical fern swamp

Striatricolpites spp. - tropical fern swamp

Triporopollenites parviannulatus - Fagaceae; swamp forest

Verrucosisporites spp. - tropical fern swamp

Palmae (landward most part of mangrove)

Longapertites psilatus

Longapertites punctatus

Lonapertites retipilatus

Longapertites sahnii

Longapertites spp.

Longapertites upliclavatus

Back mangrove (brackish swamps)

Cyathidites australis (=Coniopteris, Dicksonia)

Cyathidites minor (=Eboracia lobilolia, Dicksonia, Coniopteris, Aspidites)

Cyathidites spp.

Margocolpites spp.

Milfordia homeopunctata - aquatic herb/reed like plant, brackish water coastal environments

Retitricolporites spp. - coastal creeks

Mangroves

Echitriporites trianguliformis

Proxapertites cursus - mangrove palm

Proxapertites emendatus - mangrove palm

Proxapertites maricaiboensis - mangrove palm

Proxapertites operculatus - mangrove palm

Psilatricolpites spp. (=modern Pellicera)

Retitricolpites spp.

Spinizonocolpites admanteus (=modern Nypa)

Spinizonocolpites baculatus (=modern $\mathrm{Nypa}$ )

Spinizonocolpites echinatus' group' (=modern Nypa)

Spinizonocolpites spp. (=modern $\mathrm{Nypa})$

Information from Abbink (1998), Frederiksen (1985, 1990, 1994), Frederiksen et al. (1999), Germeraad et al. (1968).

Table 3. Palaeoenvironmental groupings of spores and pollen. 


\section{PALAEOBATHYMETRY OF THE DULJAN SUCCESSION}

Foraminiferal and palynological signals utilized for palaeobathymetric interpretation are illustrated (Figs 2 \& 3). As palynomorphs are more easily transported than foraminifera initial interpretations were undertaken using the foraminiferal data. Candidate surfaces thus identified were checked using the palynological data. IPS-determined palaeobathymetry, gammaray log and lithostratigraphy are given for all palaeontological figures to aid comparison. Abundance peaks (species and specimens) of planktonic and benthonic (calcareous and agglutinated) foraminifera and the P:B ratio correlate with peaks in palaeobathymetry and the gamma-ray log. These levels are interpreted as candidate MFSs. Conversely minimum counts of those same groups generally tie to palaeobathymetric shallowing and, in many instances, sharp-based features on the gamma-ray $\log$. These are interpreted as candidate SBs. Initial peaks in abundance between candidate SBs and candidate MFSs correlate with gamma-ray peaks between prograding and retrograding signals and are interpreted to represent initial flooding above the transgressive surface. Abundance fluctuations (species and specimens) of the shallow- and deeper-water column groups of planktonic foraminifera reveal similar trends, though, as would be expected, abundance peaks of the shallow group slightly precede those of the deeper group (e.g. c. 2800-700 $\mathrm{m}$ and c. $1100-1050 \mathrm{~m})$. This is not always the case, particularly in deeper water (outer neritic and deeper) where the deeper-water group predominates.

Peaks and troughs in dinocyst abundance (species and specimen; Figure 3) generally follow that described for the planktonic foraminifera. However, both species and specimen numbers decline when palaeobathymetry exceeds outer neritic depths, e.g. c. $2500-2300 \mathrm{~m}$. Though this is a normal trend for specimen numbers, species diversity is known to increase until middle bathyal depths (Stover \& Williams, 1982). Abundance of gonyaulacoid dinocysts follows a similar trend, while peridinaceans are much less abundant and are generally most diverse in inner-middle neritic depths (Fig. 3). The G:P ratio (specimens and species) reflects the gonyaulacoid dinocyst dominance. Abundance of proximate dinocysts is highest in shallow-water intervals, e.g. c. $2950-2500 \mathrm{~m}$.

No foraminifera were recovered from the Bara Member, Ranikot Formation. Therefore palaeobathymetry/distance from shore determinations are palynologically based. Dinocysts are rare in the lower portion of the Bara Member, only becoming common in the upper section. Abundance fluctuations of mangrove pollen (species and specimens) enable identification of four likely candidate MFSs, two of which, c. $1800 \& 2060 \mathrm{~m}$, are confirmed by dinocyst and MII abundance peaks (Fig. 3).

\section{BIOSEQUENCE STRATIGRAPHICAL FRAMEWORK OF THE DULJAN SUCCESSION}

Candidate SB and candidate MFS, identified using the ecostratigraphical signals described above, are termed 'candidate', as their regional significance could not be determined. The various abundance and diversity measurements described above confirm the shallowing and deepening trends in the IPS palaeobathymetry curve. All indices confirm the position of candidate SBs, MFSs and transgressive surfaces which are used to create a biosequence stratigraphical framework. Due to variations in depositional rate but generally equal sample spacing the biosequences identified are of variable temporal scale. Therefore, no attempt is made to distinguish second-, third- and fourth-order sequences.

Magnetobiochronological origination and extinction ages from timescale publications of Berggren et al. (1995) and Gradstein et al. (1995) and references therein are plotted in graphic correlation manner, i.e. published inception and extinction ages are used to create a 'Composite Standard Reference Section' against which the depths of inception and extinction datums of species in the well are plotted (Fig. 4). A 'line of correlation' (LOC) is drawn through these bioevents. Changes in LOC slope reflect changes in relative sedimentation rate. Nearhorizontal portions of the LOC are interpreted sensu Neal et al. $(1994,1995)$ to represent unconformities, as they correlate with major palaeobathymetric shallowings. However, at c. $2400 \mathrm{~m}$ and c. $240 \mathrm{~m}$ there is evidence for possible condensation at a flooding surface. Two major unconformities are evident. Between the Cretaceous and Tertiary at c. $2300 \mathrm{~m} \mathrm{(c.} 34 \mathrm{Ma}$ estimated missing), and the top of the Eocene at c. $240 \mathrm{~m}$ (c. $29 \mathrm{Ma}$ estimated missing). Other, shorter duration unconformities are also identified.

In addition to absolute ages determined from published ages for inception/extinction datums of individual species, series, stage and biozone data were used to date the Duljan-1 succession. This age interpretation enables tentative comparison of the Duljan-1 palaeobathymetry curve with the global eustatic curve of Haq et al. (1987). The supercycle boundaries of Haq et al. were age converted to the timescales noted above (Fig. 4). Candidate SBs identified appear to equate with eustatic supercycle boundaries. The lithostratigraphy is shown to equate reasonably with depositional sequences supporting the interpretation of the Tertiary succession in the Northern Sulaiman Ranges of Pakistan by Jones (1997). Recent detailed analysis of the Arabian plate has identified plate-wide depositional sequences, the MFSs of which have been dated (Sharland et al., 2001). Given the close proximity of the Arabian plate with the Indian-Pakistan plate throughout the Cretaceous and Tertiary a comparison of MFS dates between Arabian and the Duljan-1 succession was undertaken. In many cases the MFS dates given by Sharland et al. (2001) coincide with those determined in Duljan-1 (Fig. 4). These dates are discussed in more detail in the following section.

\section{PALAEOENVIRONMENTAL RECONSTRUCTION}

The individual depositional sequences shown largely reflect the lithostratigraphy (Fig. 4). Palaeoenvironmental determination for each sequence/formation is given in stratigraphical order.

\section{Goru Formation}

The Goru Formation of Williams (1959), subdivided into Lower and Upper units, comprises interbedded sandstones, siltstones and mudstones. The underlying Sembar Formation was not recorded. The Goru Formation penetrated was deposited from late Barremian through early Santonian in four biosequences (Fig. 4). Many smaller scale sequences are evident from wireline $\log$ analysis some of which correlate with palaeobathymetry variations for every biostratigraphical sample analysed. 


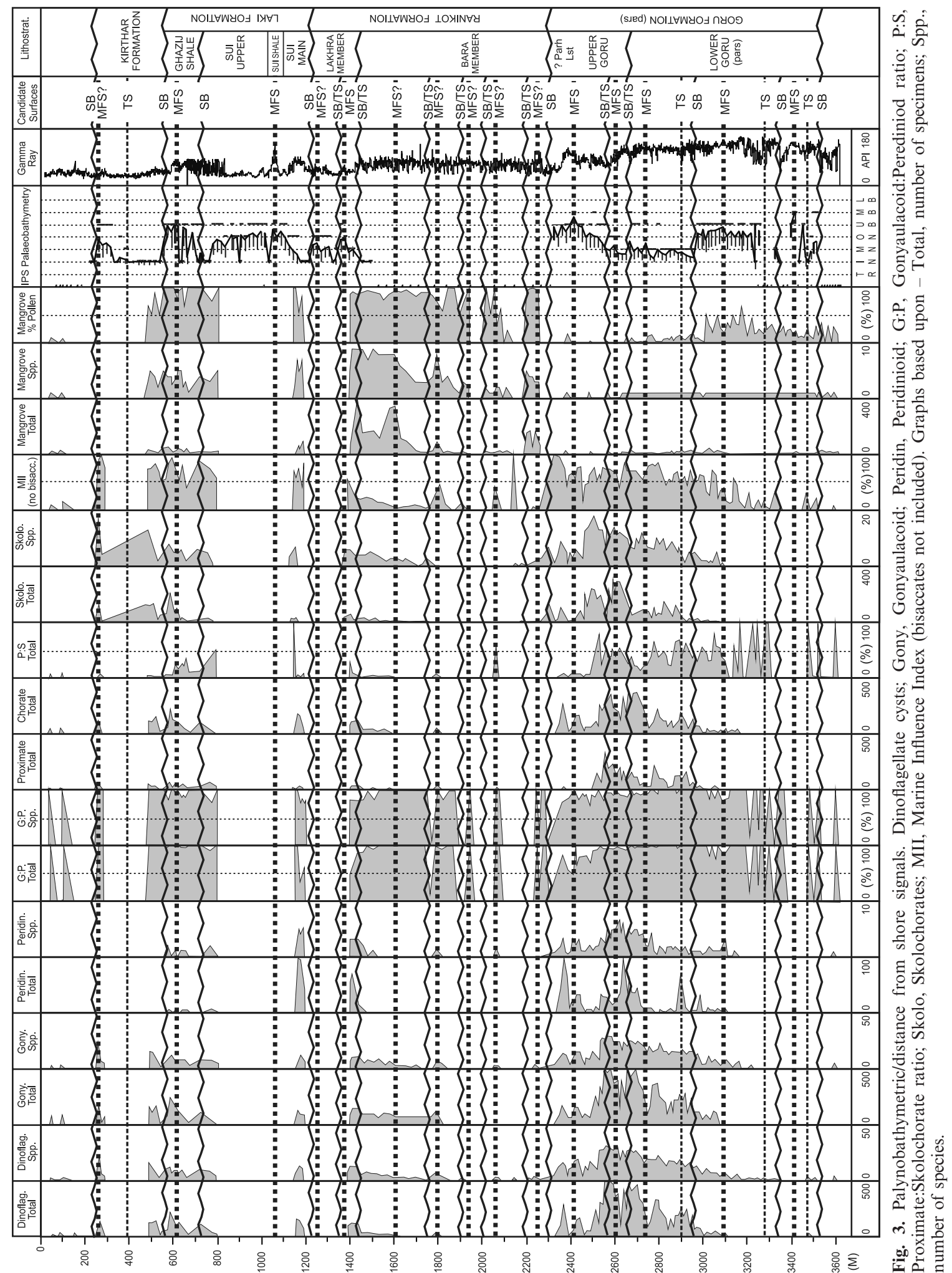


M. I. Wakefield \& E. Monteil

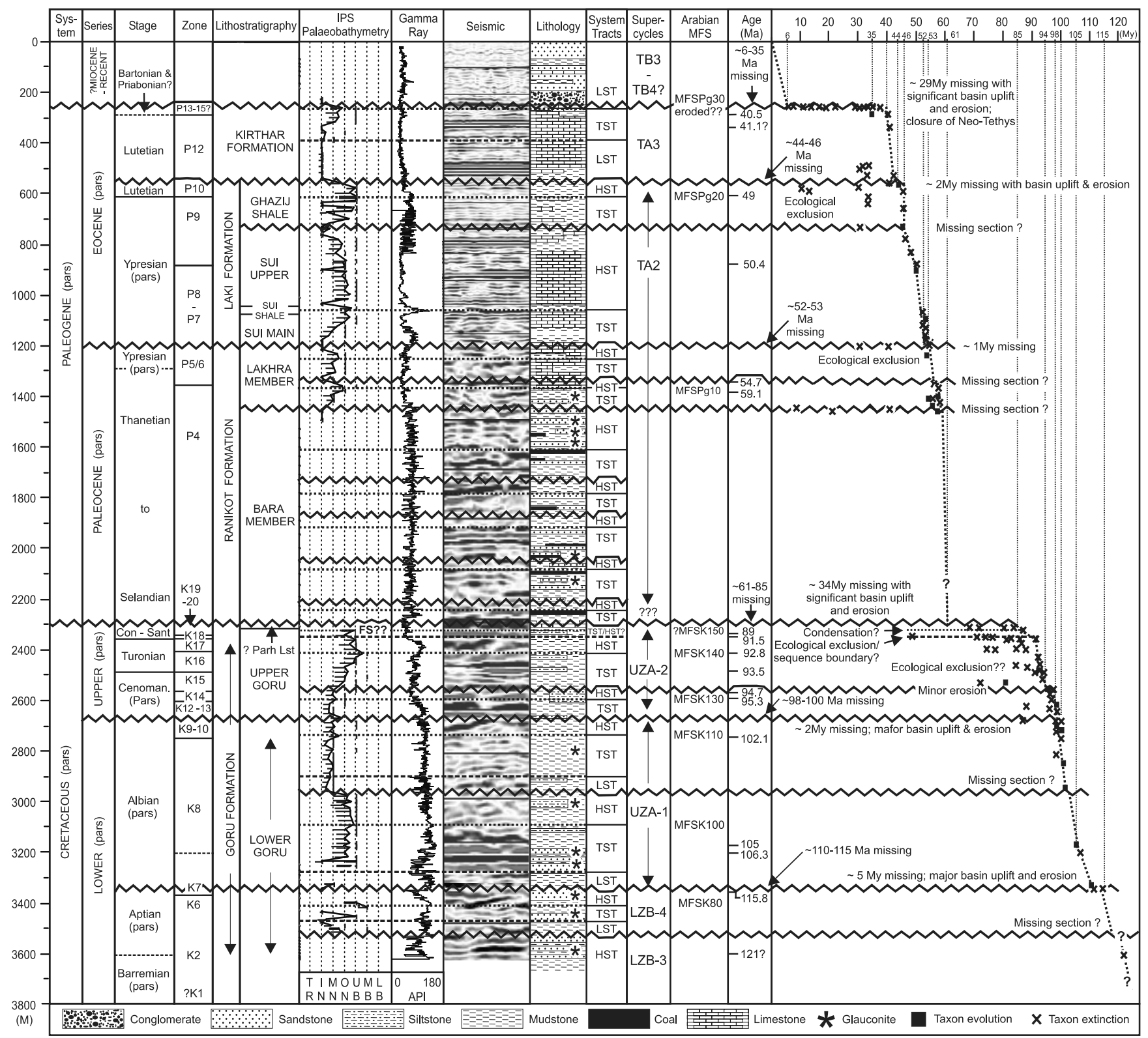

Fig. 4. Stratigraphic summary of succession from Duljan-1. Timescales used are Berggren et al. (1995; Tertiary) and Gradstein et al. (1995; Cretaceous). Eustatic supercycles from Haq et al. (1987) calibrated against timescales previously noted. A tentative correlation with MFS identified on the Arabian plate by Sharland et al. (2001) is also given. Lithological data are from the composite log; seismic data are taken from an E-W line approximating to depositional dip that runs close to well.

The Lower Goru as seen in Duljan-1 is of late Barremian through Albian age comprising dark grey, brown and black siltstones and mudstones with several thick sandstones. It is characterized by a poorly preserved and restricted foraminiferal assemblage (lenticulines and nondescript agglutinating foraminifera of 'deep' water type) in the earliest sequence $(3616-3350 \mathrm{~m})$. No planktonic foraminifera were recovered. Palynomorph recovery was poor, probably due to thermal alteration. Dinocysts are of low abundance and diversity with few stratigraphically significant taxa, e.g. a single specimen of Muderongia staurota was recorded at $3607 \mathrm{~m}$, which has a stratigraphical top in the Barremian. Pollen and spores are dominated by long-ranging taxa. Nannofloral recovery was also poor, prohibiting precise age assignment, though the presence of Rhagodiscus achylostaurion $(3361 \mathrm{~m})$ suggests an age not older than late Aptian. The interval contains common Amorphous Organic Matter (AOM), particularly in lowstand and transgressive times, associated with pale Leiospheres, while black and particularly brown wood are abundant throughout (Fig. 5). Structured wood disappears in the middle part of the sequence, while dinocysts, spores and pollen are rare throughout. Bisaccates increase their dominance from the candidate SB to the candidate MFS (Fig. 5).

The restricted foraminiferal and palynofloral assemblages suggest a restricted basin, with dysaerobic bottom waters that inhibited establishment of a good benthos but enhanced AOM 
Cretaceous-Tertiary sequence stratigraphy, Central Indus Basin, Pakistan

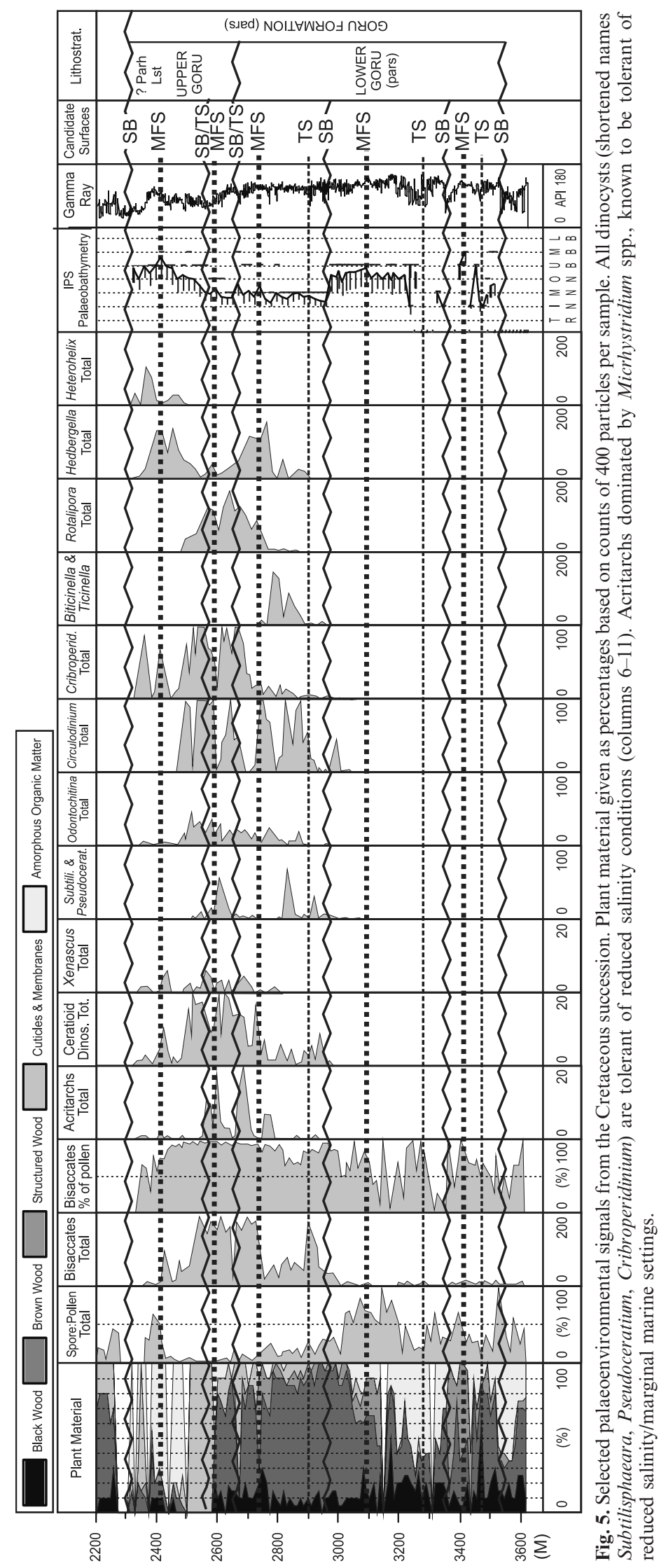


preservation. The low diversity plankton suggests that upper water column conditions were equally poor. Palaeobathymetry was $c .20-100 \mathrm{~m}$ in the sandstone intervals but reached $c .500 \mathrm{~m}$ at the candidate MFS (c. $3415 \mathrm{~m})$. Such a large bathymetric variation is considered unrealistic; the shallow bathymetric signal is considered a reflection of the source depth of the sandstones, which have a large terrestrial component (brown and black wood), often with substantial glauconite. Bisaccate dominance, particularly at the candidate MFS (c. $500 \mathrm{~m}$ water depth) suggests the 'Neves' effect with buoyant pollen being transported far from shore, possibly by a freshwater plume. This scenario would explain the paucity of plankton and, if the basin were locally silled, the dysaerobic bottom waters. The Lower Goru has been interpreted as a series of fluvio-deltaic sediments sourced from the east (Kemal et al., 1992). The sands in this interval are predominantly transgressive and highstand, while lowstand sands presumably occur further west in the depocentre. The candidate MFS in this depositional sequence is tentatively equated with MFSK80 of Sharland et al. (2001; $116 \mathrm{Ma}$, mid-Aptian).

The succeeding sequence (3350-2956 m) is Albian in age. Age data suggest that c. $5 \mathrm{Ma}$ of section is absent at the basal candidate SB (Fig. 4). There is no evidence for missing section/ time at the terminal candidate SB (Fig. 4). The candidate MFS, given the inception of Favusella washitensis (c. $105 \mathrm{Ma}$ ) at $3181 \mathrm{~m}$, is considered equivalent of the eustatically controlled MFSK100 (mid-Albian, $106 \mathrm{Ma}$ ) of Sharland et al. (2001).

Bisaccate pollen abundance increases within the sequence, while spores reach their maximum numerical abundance and diversity (Fig. 5). AOM is abundant in lowstand and transgressive times but is much reduced to absent above the candidate MFS (3091 m), while black and brown woods dominate the assemblage indicating a strong terrestrial influence (Fig. 5). An increase in dinocyst numbers is observed, including Cribroperidinium? edwardsii, Oligosphaeridium complex and Subtilisphaera spp. A numerical peak of pale Leiospheres is observed at c. $3043 \mathrm{~m}$. Planktonic foraminifera are first recorded in this sequence, e.g. Ticinella spp. (3238 m).

The distinct shallowing event at the top of this sequence was interpreted as a candidate SB. Its magnitude $(c .100 \mathrm{~m}+)$ suggests some tectonic uplift and possible erosion, though age data are insufficient to confirm the latter (Fig. 4). However, the palynology indicates a shallowing/increase in terrestrial input from c. $3000 \mathrm{~m}$ upwards that is not seen on the IPS palaeobathymetry plot and is interpreted to mark a combination of maximum highstand progradation and initiation of the SB with associated incision in the areas closest to shore. Therefore, terrestrial vegetation 'bands' will 'move' basinwards resulting in an increase in terrestrial palynomorphs in the basin thereby explaining the numbers of mangrove pollen recorded (Fig. 3). The water depth of this interval was upper bathyal. Infaunal benthonic foraminifera dominate the epifaunal forms suggesting poor bottom water conditions but ample food supplies within the sediment. Large numbers of agglutinating foraminifera support this conclusion.

The third and final Lower Goru sequence is of late Albian age based upon the following marker events; Ovoidinium scrabrosum (2646 m), Planomalina buxtorfi (2668 m) Rotalipora ticinensis $(2686 \mathrm{~m})$ and Biticinella breggiensis $(2740 \mathrm{~m})$ and the inception of Leberidocysta defloccata $(2734 \mathrm{~m})$ and Litosphaeridium siphoniphorum $(2860 \mathrm{~m})$. The occurrence of the pollen Afropollis jardinus (2836-2908 m) and Elaterocolpites castelaini (2646 m) supports an Albian age. The candidate MFS at $2740 \mathrm{~m}$ is dated as late Albian (K9) and is considered to be equivalent of MFSK110 of Sharland et al. (2001).

$P$. buxtorfi characterizes the upper part of this sequence, where it is associated with Favusella washitensis. Large numbers of small Rotalipora (gp appenninica,but with fewer chambers in the spire) may indicate adverse palaeoenvironmental conditions. The benthonic foraminiferal assemblage comprises broken, pyritized and very small, poorly defined taxa dominated by long-ranging lenticulines and agglutinates. The palynofacies is dominated by brown wood indicating a strong terrestrial influence. An influx of structured wood is noted at $2800 \mathrm{~m}$, suggesting higher energy during transgressive times (Fig. 5). Low percentages of AOM are recorded, perhaps reflecting terrestrial dilution. Acritarchs and cuticles/membranes appear in the upper part of the sequence, peaking at c. $2704 \mathrm{~m}$ and c. $2692 \mathrm{~m}$ (Fig. 5). Foraminiferal test linings appear at the top of the sequence. Dinocyst abundance and diversity increase in the basal part of the sequence. Spore abundance and diversity decrease up the sequence. The peak in spores and bisaccates reflects maximum lowstand progradation (c. 2900 m; Fig. 5).

This sequence was deposited at approximately middle neritic water depths, though there does appear to be a subtle deepening uphole that is more clearly emphasized by the increase of the P:B ratio and a general increase in marine palynological indicators (Figs 2 \& 3). Near-shore lower salinity conditions are suggested by the dominance of ceratioid and proximate dinocysts (Figs 3 \& 5). Glauconite-rich sediments suggest low sedimentation rates. Minor flooding events were noted at $2668 \mathrm{~m}, 2740 \mathrm{~m}$ (gamma peak, increase in bathymetry, diversity and P:B ratio) and at $2794 \mathrm{~m}$ (abundance of dinocysts). Palynological data indicate shallowing between $2704 \mathrm{~m}$ and $2692 \mathrm{~m}$, which corroborates IPS palaeobathymetry (Fig. 3). The occurrence of Hedbergella spp. mirrors the prograding gamma-ray trend, peaking at the candidate MFS $(2740 \mathrm{~m})$. Work on late Albian successions in Italy (Galeotti, 1998) has shown that a dominance of Hedbergella, accompanied by low diversity benthonic foraminiferal assemblage suggests well-mixed eutrophic waters. Hedbergella are considered by Leckie $(1987,1989)$ to be 'the weeds of the mid-Cretaceous oceans, dominating the sun-lit near-surface waters of the mixed layer and/or upper reaches of the thermocline, where trophic resources are concentrated'. Rotalipora are rare in lowstand and early transgressive times but rapidly increase in abundance at the candidate MFS. Rotalipora has been interpreted as an indicator of normal marine waters within a well-stratified water column (Leckie 1987, 1989) and lives below $100 \mathrm{~m}$ in the water column. The environment of deposition postulated during transgressive times (2956-2740 m) underwent cyclic changes in water mass stability; peaks in abundance of Biticinella/Ticinella, indicative of a low productivity (oligotrophic) stratified water column, counter-correlate with peaks of Hedbergella spp. and the dinocyst Circulodinium spp, indicative of a nutrient-rich non-stratified water column. There is a distinct change in this oscillation at c. $2780 \mathrm{~m}$, below which Biticinella/Ticinella are dominant over Hedbergella spp. The disappearance of Biticinella/Ticinella coincides with the 
MFS at $2740 \mathrm{~m}$. The replacement of Ticinella by Hedbergella, which lives slightly shallower in the water column, during the transgression, could also indicate expansion of the oxygen minimum zone sensu Leckie (1987). The 'restricted' basinal conditions recorded in earlier Lower Goru sequences are only evident in the lowstand of this sequence. The presence of planktonic foraminifera suggest either 'surface' water conditions were more hospitable, or that bottom water conditions had improved allowing their preservation. The occurrence of Xenascus spp., particularly in the highstand, indicate some input of estuarine water (J-M Moron, pers. comm. 1991) which would not affect the deeper-living Rotalipora but restrict shallowerwater planktonic foraminifera (Figs. $2 \& 5$ ) that may explain the low numbers of Globigerinelloides and the 'blue-water' dinocyst Pterodinium within the highstand sediments. Hallock (1987) and Coccioni et al. (1993) interpret these taxa as indicative of oligo-mesotrophic conditions. The occurrence of Xenascus spp. generally correlates with the decrease in Hedbergella spp. Palynological data confirm water mass instability suggested by the planktonic foraminifera and indicate increased terrestrial runoff as a possible control. Water mass instability continued during Upper Goru deposition.

The incomplete Upper Goru Formation, which is early Cenomanian through Santonian in age, is terminated by a significant unconformity of some $34 \mathrm{Ma}$, indicating basinal uplift and erosion (Fig. 4). There is $2 \mathrm{Ma}$ of missing section at the basal unconformity. Clear evidence has not been found for typical Parh Formation carbonates. However, calcareous mudstones, noted by mud loggers, may represent a basinal equivalent of the Parh limestones, though it is probable that the Parh, in addition to Mughal Kot and Pab Sandstone formations, was eroded from this locality.

Interval age and zones are based upon the following marker events; the closely occurring highest occurrences of Rotalipora cushmani (K15), R. reicheli (K14), R. brotzeni (K13) and $R$. montsalvensis (2472-2580 m) suggest condensation, i.e. all the Rotalipora zones of Shafique \& Daniels (1990). This condensed section coincides with a candidate MFS at c. $2598 \mathrm{~m}$ dated at c. $95 \mathrm{Ma}$ (plankton zone K14) that is considered to be equivalent of MFSK130 of Sharland et al. (2001) immediately overlain by a candidate SB with minor erosion (Fig. 4). The second candidate MFS identified in the Upper Goru (c. $2418 \mathrm{~m}$ ) is dated at c. $92 \mathrm{Ma}$ (early K17). Sharland et al. (2001) define their MFSK140 as occurring in the earliest Turonian Whiteinella archaeocretacea plankton zone and give a date of c. 93 Ma i.e. late K16. Given the generally close age determination and the errors associated with the use of ditch cuttings in the current study these MFSs are considered as being possible equivalents. Sharland et al.(2001) date their MFSK150 at $88 \mathrm{Ma}$. No clear evidence of an MFS was seen in the equivalent-aged succession in Duljan-1 (Figs. 2, 3) though evidence of possible condensation associated with a slight palaeobathymetric increase (c. $2327 \mathrm{~m}$ ) are indicated by age data (Fig. 4).

Other zonal markers include the highest occurrence of Helvetoglobotruncana praehelvetica and Marginotruncana sinuosa (2346 m; K17\&18). Between $2346 \mathrm{~m}$ and $2472 \mathrm{~m}$ wellpreserved planktonic taxa including M. schneegansii, Whiteinella paradubia, Dicarinella hagni and D. concavata occur. Benthonic taxa are small, variably preserved rotalids, buliminids and some agglutinates. Well-preserved Globotruncana bulloides, G. lapparenti, M. coronata, M. pseudolinneiana, M. marginata, Praeglobotruncana stephani and $P$. delrioensis indicate an early Senonian/Turonian age (2309-2346 m). The highest occurrence of Epelidosphaeridia spinosa $(2574 \mathrm{~m})$ indicates an early to middle Cenomanian age. Other taxa consistent with this age determination include the highest occurrence of Litosphaeridium arundum, Prolixosphaeridium conulum and Endoceratium dettmanniae $(2598 \mathrm{~m})$. An early Cenomanian age is indicated by the occurrence of the nannofossils Gartnerago chiasta in association with Axopodorhabdus albianus, Cretarhabdus striatus, Radiolithus planus and Gartnerago 'ponticulus' at $2650 \mathrm{~m}$. The highest occurrence of the dinocyst Xenascus sarjeantii (2442 m) tentatively supports a Turonian age.

Rotalipora dominate the microfauna in the basal sediments, though these rapidly decline in abundance to be successively replaced in dominance by Hedbergella and Heterohelix (Fig. 5). Benthonic foraminifera include broken lenticulines and agglutinates with Dorothia filiformis, Eggerellina spp. and Epistomina spp.

Palynologically, three events characterize the interval 2610 $2544 \mathrm{~m}$ : absence of AOM, abundance of cuticles/membranes, and a peak in diversity and abundance of dinocysts (Fig. 5). Foraminiferal test linings and acritarchs are also present. The maximum concentration of AOM and sudden decrease in dinocyst abundance and diversity occurs between $2544 \mathrm{~m}$ and $2334 \mathrm{~m}$ accompanied by a change in the planktonic foraminiferal fauna. Black and structured wood, Leiospheres and Pediastrum occur sporadically throughout this sequence. Spore and pollen diversity is low, while pollen abundance decreases and spore abundance increases towards the top of this sequence (Fig. 5).

The marked kerogen change at $2622 \mathrm{~m}$ (incoming of AOM and woody material) probably reflects Cenomanian drowning of the Lower Goru deltaics. The Upper Goru has been interpreted as a major flooding event (Kemal et al., 1992). The dominance of cuticles/membranes, maximum diversity and abundance of dinocysts (particularly Odontochitina spp.) and common acritarchs suggest an outer shelf environment that was influenced by the input of low salinity waters (consistent presence of Xenascus spp. and rare freshwater algae, Pediastrum) between $2610 \mathrm{~m}$ and $2544 \mathrm{~m}$ (Fig. 5). The increased abundance of spores/pollen in association with woody materials suggests strong terrestrial runoff. Marked changes in water mass conditions, continuing from those recorded in the Lower Goru (c. 2630-2750 m), are indicated by abundance variations in Hedbergella spp. and Rotalipora spp. Hedbergella increase in abundance throughout the transgressive interval (Fig. 5) accompanied by a marked reduction in benthonic diversity, particularly the epifauna, suggesting elevated nutrient levels in the water column but poorer, possibly kenoxic bottom water conditions that enhanced AOM preservation. Perversely dinocyst species diversity decreases in this interval (Fig. 3). As preservation appears good then water mass conditions remain the obvious cause of their reduction. Stratigraphically, this interval broadly equates with the 'Black Band' anoxic event seen in NW Europe. Following the candidate MFS (maximum gamma, P:B ratio, total plankton and diversity; $2420 \mathrm{~m}$ ) Hedbergella spp. abundance rapidly decreases while Heterohelix spp. increase (Fig. 5). This taxon succession 


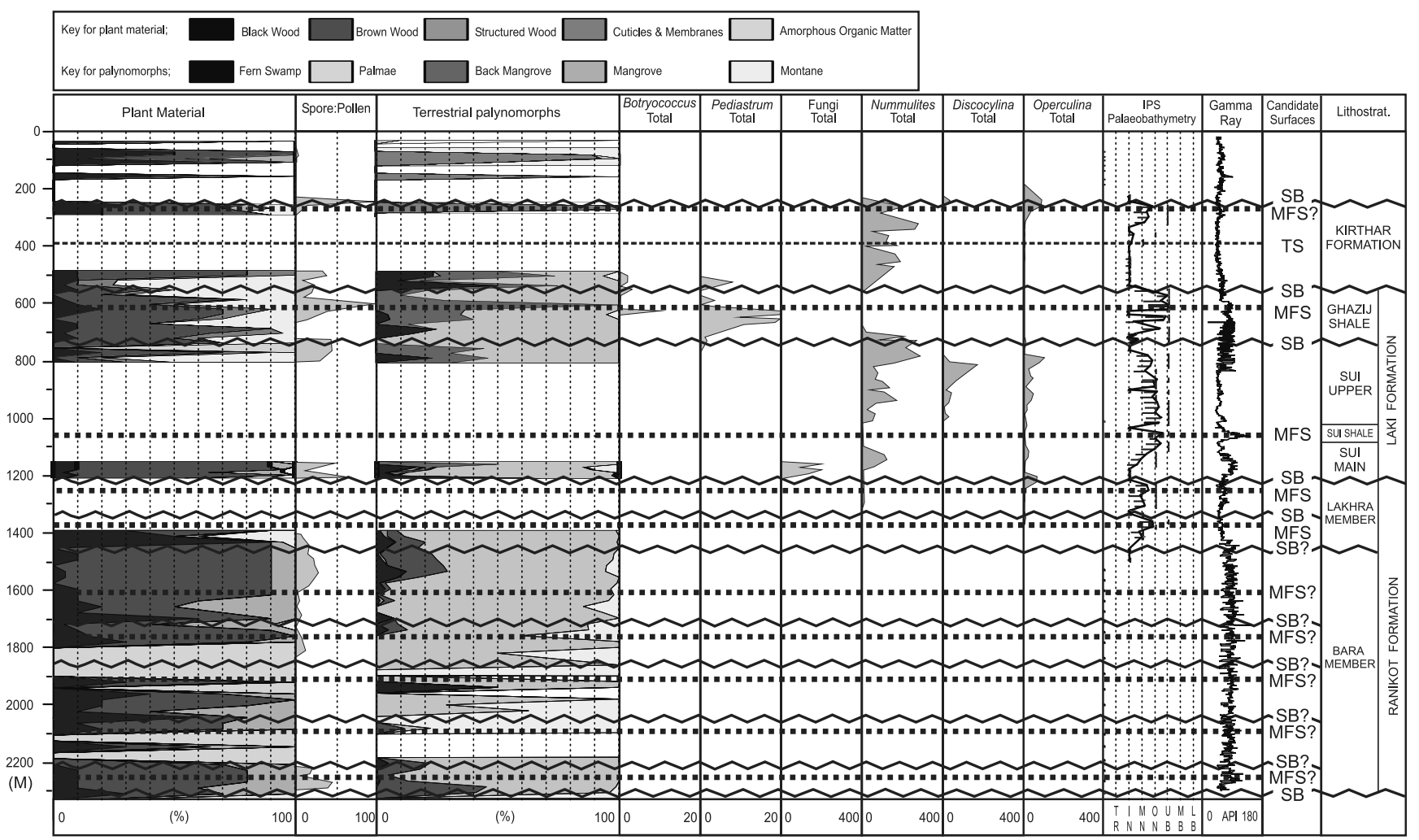

Fig. 6. Selected palaeoenvironmental signals from the Tertiary succession. Plant material given as percentages based on counts of 400 particles per sample.

indicates water mass changes from high nutrient levels (Hedbergella spp.) to poorer more stressful conditions (Heterohelix spp.). Heterohelix is considered eurytopic and indicative of more stressful conditions (lower salinity and/or oxygen) than Hedbergella, (Leckie et al., 1991, 1998) and has been used as a proxy for water column stratification, including an expanded oxygen minimum zone (Leckie et al., 1991). The latter control is considered more likely in this sequence as low salinity indicators, e.g. Xenascus spp., counter-correlate with Heterohelix abundance (Fig. 5). Heterohelix is known to have proliferated during the expansion of epicontinental seas during the late Cenomanian-Turonian OAE-2. Calcareous benthonic foraminiferal diversity is low when Heterohelix spp. and agglutinating foraminifera were abundant.

\section{Ranikot Formation}

The late Palaeocene Ranikot Formation of Blanford (1879) has two members; Lakhra (1167-1427 m) and Bara (1427-2309 m). Interval age and zones are based upon the highest occurrence of common Apectodinium spp. $(1169 \mathrm{~m})$, the presence of a Nummulites/AssilinalRotalial Alveolina assemblage, the presence of DaviesinalMiscellanea and Kathina below 1262 m, the highest occurrence of Echitriporites trianguliformis (1425 m) and Spinizonocolpites baculatus $(1425 \mathrm{~m})$. The presence of Fasciculithus spp., Neochiastozygus distentus, Toweius tovae and T. callosus (1337 m) and Fasciculithus tympaniformis, Ellipsolithus macellus, Prinsius bisulcus, N. imbrei, Chiasmolithus spp., Zygodiscus herlyni, T. pertusus and $N$. distentus $(1367 \mathrm{~m})$ confirm a late Palaeocene age. No evidence for lowermost Palaeocene sediments was found.

The Bara Member comprises green-grey, red-brown and grey-brown mudstones with common glauconite and occasional coals. No foraminifera were recorded in the micropalaeontological preparations. Black and brown wood, as well as cuticles and membranes, are the main components of the palynofacies in the basal $300 \mathrm{~m}$. AOM, dinocysts, acritarchs, algae and foraminiferal tests linings were rare. Fungal fruiting bodies are common. A more or less palynologically barren interval of red mudstones follows (2015-1847 m). Cuticles and membranes are common along with a low but increasingly diverse dinocyst assemblage in the overlying sediments (1847-1403 m; Fig. 3). The top of this sequence is marked by the reappearance of AOM, and another peak in black wood coinciding with the disappearance of brown wood (Fig. 6). A clear increase in spore and pollen abundance and diversity is observed from the bottom of this sequence. Mangrove pollen is dominant, including Spinizonocolpites echinatus 'group' fluctuations, which suggest flooding events (Fig. 3). Palmae (Longapertites retipilatus, L. psilatus and L. upliclavatus) occur in the top $300 \mathrm{~m}$, along with back mangrove (Cyathidites minor) and fern swamp elements (Laevigatosporites spp.); see Figure 6.

Palynological evidence indicates a shallow marginal marine, mangrove swamp palaeoenvironment supporting the interpretation of Kemal et al. (1992). The general lack of foraminifera, though appearing to confirm marginal marine conditions, 
probably results from decalcification indicated by rare foraminiferal test linings in the palynological residues. The Bara Member was rapidly deposited: c. $900 \mathrm{~m}$ in c. $5 \mathrm{Ma}$ (Fig. 4). At least five depositional sequences, with trangressive and highstand sediments are interpreted from palynological evidence (Fig. 3). Conditions were generally near shore, though inland (drier?) palynomorphs are recorded above $1600 \mathrm{~m}$ (Fig. 6).

The carbonates and mudstones of the Lakhra Member contain shallow marine, larger foraminifera, and deep-water, planktonic foraminifera. There is a faunal change associated with the lithological change at the top of the succession comprising brown and green mudstones, quartz sand, glauconite and siderite. Microfossils are rare in the basal 'greensands'. Larger foraminifera, mainly Nummulites spp. and Assilina spp., dominate over larger foraminifera including Alveolina, Rotalia, Kathina, Daviesina/Miscellanea, Discocyclina, Lockhartia, Goupillaudina and Faujasina. Ranikotothalia spp., characteristic of the type Lakhra in Sind are present (1322-1340 m). Keeled Morozovella, including M. aequa, M. edgari, M. acuta and $M$. angulata, dominate the fauna between $1358 \mathrm{~m}$ and $1376 \mathrm{~m}$, indicating a $\mathrm{P} 4 / 5 / 6$ age. The increase in Apectodinium spp., including $A$. homomorphum, A. parvum, A. quenquelatum and the record of a questionable specimen of $A$. augustum, indicate a late Palaeocene age.

Two depositional sequences are interpreted from palaeobathymetric evidence (Figs 2, 4 \& 6). Water depths varied between inner to outer neritic/upper bathyal. Morozovella lives below $100 \mathrm{~m}$ in the water column, its cyclical occurrence suggesting major vertical movements in the basin. Candidate MFSs are identified at $c .1370 \mathrm{~m}$ and $c .1232 \mathrm{~m}$. The former occurs near the top of plankton zone P4 and is probably equivalent of MFSPg10 of Sharland et al. (2001). The latter occurs in plankton zone P5/6, for which there is no equivalent MFS identified in Sharland et al. (2001).

The Lakhra was deposited in a deeper-marine palaeoenvironment than the Bara, perhaps in front of any mangrove swamps. The abundance of Apectodinium spp., associated with brown wood and cuticles/membranes, indicates a nearby brackish environment, while the varied, larger benthonic fauna, indicate oligotrophic shallow-water open marine conditions within the photic zone. The Bara carbonates represent widespread transgression of the Ranikot shelfal system (Kemal et al., 1992). Biostratigraphical evidence of significant erosion at the bounding candidate SBs of the Lakhra is absent (Fig. 4).

\section{Laki Formation}

The Laki Formation (Ypresian to early Lutetian) comprises the Sui Main Limestone and Ghazij members. Interval age and zones are based upon the highest occurrence of Nummulites crasseornata, Assilina cf. pustulosa, N. globulus, A. laminosa, Discocyclina cf. ranikotensis, $N$. fossulata and Operculina cf. jiwani, small rotalids including Cibicidoides ungerianus and the dinocyst Eatonicysta ursulae. The nannofossils Campylosphaera dela, in association with Toweius spp. (including T. magnacrassus), and Rhomboaster spp., confirm an early Eocene age. The record of Discoaster diastypus, Sphenolithus editus and $S$. radians $(1106 \mathrm{~m})$ indicates zones CP9b/10. The Sui
Shale candidate MFS $(1052 \mathrm{~m})$ is dated as plankton zone P7 (c. $51 \mathrm{Ma}$ ), while the Ghazij Shale candidate MFS is dated as being from the late Ypresian plankton zone P9 (c. 49 Ma). The Ghazij Shale candidate MFS is considered to be equivalent of MFSPg20 of Sharland et al. (2001).

The Sui carbonates, informally subdivided into Sui Main, Sui Shale and Sui Upper, are characterized by a gradually changing foraminiferal fauna. Brown wood and mangrove pollen dominate, with common fungi in the basal sediments of the Sui Main (Fig. 6). Immediately following this interval Nummulites spp., $N$. globulus and A. laminosa briefly flourish before a deeper-water fauna, including Morozovella spp., M. aequa and M. quetra, appears (Figs $2 \& 6$ ). The base of the Sui Shale (calcareous mudstones) is marked by a reduction in planktonic foraminiferal diversity (specimen and species), a P:B peak and common radiolaria. The white to yellow brown limestones of the Sui Upper contain dominant rotalids and abundance fluctuations of Nummulites and DiscocyclinalOperculina suggesting frequent subtle changes in water depth and water mass condition (Nummulites indicate oligotrophic conditions; Fig. 6). Few planktonic foraminifera are present but include Acarinina pentacamerata and Pseudohastigerina cf. wilcoxensis. Broken and encrusted foraminifera at the top of the sequence are interpreted as evidence of a candidate SB. There may be a substantial time break at this level, but currently available age data are insufficient to quantify this; however, the depositional rate clearly declines between $c$. $50 \mathrm{Ma}$ and $46 \mathrm{Ma}$ (Fig. 4).

Initial shallow-water conditions, with evidence of local mangrove swamps (Spinizonocolpites spp., S. echinatus 'group' and fungi) prevailed during deposition of the basal Sui Main carbonates. Fungi indicate rotting vegetation, probably from the nearby mangrove swamp. Apectodinium spp., A. homomorphum and $A$. parvum confirm reduced salinities. Water depth rapidly increased, culminating at the candidate MFS, with the deposition of the Sui Shale that is probably equivalent of widespread mudstone deposition attributed to a relative sea-level rise in the Loti area to the NW (Iqbal et al., 1994). The presence of radiolaria suggests increased water column nutrient levels during the short-lived transgression. These deep-water mudstones were rapidly replaced by regressive carbonates of the Sui Upper deposited in shallow waters containing abundant Nummulites and Discocyclina (Fig. 6).

The Ghazij Shale Member (late Ypresian to early Lutetian) comprises pale grey laminated mudstones with limestone stringers. Few age-significant taxa were recovered, though the dinocysts Polysphaeridium subtile, Homotryblium pallidum and Thalassiphora patula were recorded. The assemblages are similar to, though more restricted than, the Baska Formation fauna described from the Sulaiman Range (Jones, 1997). The basal evaporites noted by Jones are not present in Duljan-1, neither were the interbedded alabaster and gypsiferous limestones of Hemphill \& Kidwai (1973). The larger foraminifera found in this sequence generally appear to be caved from the overlying carbonates. Small agglutinating taxa with strong ferruginous staining are considered in situ, while rare, small rotalids and pustulose Nummulites associated with carbonate bands containing bivalves, gastropods, fish teeth and vertebrae occur sporadically. AOM and cuticles/membranes dominate the palynofacies (Fig. 6). A marked increase in foraminiferal test lining 
abundance is observed throughout the sequence. Some specimens of the Chlorococcale algae Botryococcus and Pediastrum are seen in the transgressive unit, suggesting occasional freshwater influence or reworking of underlying freshwater sediments (Fig. 6). Spore and pollen abundance/diversity are very low, but a slight increase is observed at the top of the unit. Mangrove taxa (S. echinatus 'group', Cyathidites minor, Proxapertites operculatus and Psilatricolpites spp.) though rare, dominate the pollen assemblage (Figs $3 \& 6$ ). Foraminiferal evidence indicates deepening to outer neritic/upper bathyal water depths (Fig. 2). The peak in dinocysts at $c .600 \mathrm{~m}$ ties to the deeper-water conditions indicated by the foraminifera. AOM preservation may therefore be attributed to lower oxygen bottom waters, a hypothesis supported by the increase in agglutinate and decrease in epifaunal benthonic foraminifera. The Ghazij Shale appears to be a predominantly transgressive/highstand basinal deposit as postulated by previous work (Kemal et al., 1992, Iqbal et al., 1994). Mangrove pollen was probably transported down slope into the basin. Significant basin uplift and erosion at the end of the sequence is indicated by both palaeobathymetric and age data (Fig. 4).

\section{Kirthar Formation}

The Kirthar Formation (Lutetian/Bartonian-Priabonian?) comprises the Habib Rahi Limestone, Sirki/Domanda Shale and Pirkoh Limestone members. This depositional sequence is truncated by a significant unconformity representing c. $29 \mathrm{Ma}$ (Fig. 4). The presence of the planktonic foraminifera Orbulinoides beckmanni, Morozovella spinulosa and Truncorotaloides topilensis near the top of the sequence enables confident dating; planktonic zone P13. A mid-Eocene age is confirmed by the co-occurrence of the dinocysts Enneadocysta multicornuta, Homotryblium floripes, H. pallidum 'complex' and Cleistosphaeridium placacanthum. However, the presence of Truncorotaloides libayensis, Cribroperidinium guiseppei, Homotryblium tenuispinosum 'complex', Polysphaeridium subtile, Nummulites beaumonti and $N$. chavannesi indicate that upper Eocene (P14 \& P15) sediments are also present, suggesting a condensed stratigraphy. The occurrence of Calcidiscus protoannula (a mid-late Eocene restricted taxon) and Cyclicargolithus floridanus (no older than Middle Eocene), common Reticulofenestra minuta in association with $R$. dictyoda, multi-rayed Discoaster spp. and Zeugrhablithus bijugatus (CP12 or younger) confirm the age determination. This condensed interval coincides with a candidate MFS at $242 \mathrm{~m}$ dated as mid-late Eocene (40-35 Ma) and is older than MFSPg30 (Rupelian, early Oligocene, $33 \mathrm{Ma}$ ) of Sharland et al. (2001). However, it is possible that the marked erosion at the top of this sequence that is associated with closure of Neo-Tethys has removed the actual MFS, i.e. the candidate MFS currently identified is actually a minor flooding surface within the TST.

Palaeobathymetry deepened from inner neritic at the base of the sequence to outer neritic, which is tentatively interpreted to be a candidate MFS ( $242 \mathrm{~m}$ ), a deepening trend mirrored by the decrease of shallower-water taxa (e.g. Nummulites) and the increase of deeper-water Discocyclina and Operculina (Fig. 6). Transgressive and highstand sediments contain the only plankton in the sequence. Dinocysts and planktonic foraminifera are of low diversity. The palynofacies is dominated by brown wood at the base, which decreases upwards as AOM increases. Spores and pollen are rare. Mangrove elements are dominant, though drier climatic indicators (back mangrove and fern elements) increase upwards (Fig. 6). This interpretation supports the 'restricted lagoons' of Quadri \& Shuaib (1986) and the 'rapid westward progradation of ramp carbonate intervals' of Kemal et al. (1992).

\section{Siwalik Group}

The Recent to Plio-Miocene Siwalik Group, comprising the Gaj and Manchar formations, is dated on regional geological evidence, the recovered biota being of little stratigraphical importance. Sediments comprise ferruginous basal conglomerates with subangular to rounded quartz and lithic clasts that appear to have been deposited in non-marine conditions. Foraminifera were rare, derived, yellow-stained, fragmentary Assilina spp. and Nummulites spp. Palynological recovery was also poor, with few dinocysts. Pollen and spores were recorded in low numbers, including Inaperturopollenites hiatus, Alnipollis verus, bisaccate pollen and Steriesporites spp. The main palynofacies components are black and brown wood (Fig. 6).

\section{SUMMARY}

Detailed palaeobathymetry determinations, combined with other palaeontological signals, have enabled identification of 15 depositional sequences bound by candidate SBs and containing candidate MFSs. This number may be increased to 16 if an equivalent to MFSK150 of Sharland et al. (2001) is confirmed at c. $2327 \mathrm{~m}$. These sequences require testing in a regional context. However, several of the candidate MFSs identified have similar ages to MFSs identified on the nearby Arabian plate by Sharland et al. (2001). The sequences defined between these critical stratigraphic surfaces generally reflect the lithostratigraphy supporting the findings for the Tertiary succession in the Sulaiman Range, Pakistan by Jones (1997). Significant uplift and erosion were recorded at the end of the Cretaceous (c. $34 \mathrm{Ma}$ missing) and Eocene (c. $29 \mathrm{Ma}$ missing), the latter coinciding with closure of Neo-Tethys.

Environmental interpretations from micropalaeontology and palynology are complementary. In particular fluctuations of planktonic foraminifera and palynomorphs/sporomorphs/ phytoclasts enable detailed water mass changes within the central Indus Basin to be defined. Palynological data suggest these changes are attributable to variable terrestrial/freshwater input.

\section{ACKNOWLEDGEMENTS}

We wish to thank the Government of Pakistan and BG Group for permission to publish. We also wish to thank the Technical Alliance for Computational Stratigraphy for the use of the IPS software. Andy Racey, Mark Setrem, Abdul Waheed and Mike Wilkes (BG Group), Deryck Bayliss and Jeffrey Goodall and two un-named reviewers are thanked for invaluable assistance and suggestions.

\section{Manuscript received 25 June 2001 Manuscript accepted 16 May 2002}




\section{REFERENCES}

Abbink, O.A. 1998. Palynological investigations in the Jurassic of the North Sea Region. LPP Contributions Series, 8. LPP Foundation, Utrecht, 1-192.

Ahmed, H., Cheema, M.R., Fatima, A.N., Iqbal, M.W.A., Raza, H.A., Raza, S. \& Ibrahim-Shah, S.M. 1977. Stratigraphy of Pakistan. Memoir, Geological Survey, Pakistan, 12.

Albers, C.C., Bane, M.R., Dorman, J.H., Dunlop, J.B., Lampton, J.M., Macomber, D., Martin, G.B., Parrott, B.S., Skinner, H.C., Sylvester, R.K. \& Ventress, W.P.S. 1966. Foraminiferal ecological zones of the Gulf Coast. Gulf Coast Association of Geological Societies, Transactions, 16: 345-348.

Armentrout, J.M. 1987. Integration of biostratigraphy and seismic stratigraphy: Pliocene-Pleistocene, Gulf of Mexico. Innovative Biostratigraphic Approaches to Sequence Analysis: New Exploration Opportunities. Gulf Coast Section Society of Economic Paleontologists and Mineralogists, Eighth Annual Research Conference: $6-14$.

Armentrout, J.M. 1996. High resolution sequence biostratigraphy: Examples from the Gulf of Mexico Plio-Pleistocene. In: Howell, J.A. \& Aitken, J.F. (Eds), High Resolution Sequence Stratigraphy: Innovations and Applications. Geological Society London, Special Publication, 104: 65-86.

Armentrout, J.M. \& Clement, J.F. 1990. Biostratigraphic calibration of depositional cycles: A case study in High Island-GalvestonEast Banks areas, offshore Texas. In: Armentrout, J.M. \& Perkins, B.F. (Eds), Sequence Stratigraphy as an Exploration Tool: Concepts and Practices in the Gulf Coast. Gulf Coast Section Society of Economic Paleontologists and Mineralogists, Eleventh Annual Research Conference: 21-51.

Armentrout, J.M., Echols, R.C. \& Lee, T.D. 1990. Patterns of foraminiferal abundance and diversity: Implications for sequence stratigraphic analysis. In: Armentrout, J.M. \& Perkins, B.F. (Eds), Sequence Stratigraphy as an Exploration Tool: Concepts and Practices in the Gulf Coast. Gulf Coast Section Society of Economic Paleontologists and Mineralogists, Eleventh Annual Research Conference: 53-59.

Baum, G.R. \& Vail, P.R. 1988. Sequence stratigraphic concepts applied to Paleogene outcrop, Gulf and Atlantic Basins. In: Wilgus, C.K., Hastings, B.S., Kendall, C.G.St.C., Posamentier, H.W., Ross, C.A. \& Van Wagoner, J.C. (Eds), Sea-Level Changes: An Integrated Approach. Society of Economic Paleontologists and Mineralogists, Special Publication, 42: 302-327.

Be, A.W.E. 1977. An ecological, zoogeographic and taxonomic review of Recent Planktonic Foraminifera. In: Ramsey, A.T.S. (Ed.), Oceanic Micropaleontology, 1. Academic Press, 1-100.

Berggren, W.A., Kent, D.V., Swischer, C.C. III \& Aubry, M.P. 1995. A revised Cenozoic geochronology and chronostratigraphy. In: Berggren, W.A., Kent, D.V., Aubry, M.P. \& Hardenbol, J. (Eds), Geochronology, Time Scales and Global Correlations. Society of Economic Paleontologists and Mineralogists, Special Publication, 54: 129-212.

Blanford, W.T. 1879. The geology of western Sind. Memoir, Geological Survey of India, XVII(1).

Bujak, J.P. 1984. Cenozoic dinoflagellate cysts and acritarchs from the Bering Sea and Northern North Pacific, D.S.D.P. Leg 1. Micropaleontology, 30: 180-212.

Chaloner, W.G. \& Muir, M. 1968. Spores and floras. In: Murchison, D. \& Westoll, T.S. (Eds), Coal and Coal Bearing Strata. Elsevier, New York, 127-146.

Charnock, M.A. \& Jones, R.W. 1990. Agglutinated foraminifera from the Palaeogene of the North Sea. In: Hemleben, C., Kaminski, M.A., Khunt, W. \& Scott, D.B. (Eds), Paleoecology, Biostratigraphy, Paleoecology and Taxonomy of agglutinating Foraminifera. Kluwer Academic Publishers, Dordrecht, 139-144.

Coccioni, R., Galeotti, S. \& Santarelli, A. 1993. Preliminary palynological analysis of the Maiolica-Scisti a Fucoidi transition (BarremianAptian) in the Gorgo a Cerbara section (central Italy). Palaeopelagos, 3: $199-205$.

Culver, S.J. 1988. New foraminiferal depth zonation of the northwestern Gulf of Mexico. Palaios, 3: 69-85.
Davey, R.J. 1971. Palynology and palaeoenvironmental studies with special reference to the continental shelf sediments of South Africa. In: Farinacci, A. (Ed.), Proceedings of the 2nd Planktonic Conference Roma, 1970, 1. Edizioni Technoscienza, Rome.

Davey, R.J. \& Rogers, J. 1975. Palynomorph distribution in Recent offshore sediments along two traverses off southwest Africa. Marine Geology, 18: 213-225.

Downie, C., Hussain, M.A. \& Williams, G.L. 1971. Dinoflagellate cyst and acritarch associations in the Paleogene of Southeast England. Geoscience and Man, 3: 29-35.

Eames, F.E. 1952. A contribution to the study of the Eocene in western Pakistan and western India; Part A. The geology of standard sections in the western Punjab and in the Kohat District. Geological Society of London, Quarterly Journal, 107(2): 159-171.

Emery, D. \& Myers, K.J. 1996. Sequence Stratigraphy. Blackwell Science, Oxford: 1-297.

Eshet, Y., Almogi-Labin, A. \& Bein, A. 1994. Dinoflagellate cysts, paleoproductivity and upwelling systems: a Late Cretaceous example from Israel. Marine Micropaleontology, 23: 231-240.

Frederiksen, N.O. 1985. Review of early Tertiary sporomorph paleoecology. American Association of Stratigraphic Palynologists, Contributions Series, 15: 1-92.

Frederiksen, N.O. 1990. Palynological contribution to geologic mapping of coal-bearing upper Paleocene rocks in the Lower Indus coal region, Pakistan. United States Geological Survey Open-File Report 90-243, and Project Report to the Geological Survey of Pakistan (IR)PK-87: $1-40$.

Frederiksen, N.O. 1994. Middle and Late Palaeocene Angiosperm Pollen from Pakistan. Palynology, 18: 91-137.

Frederiksen, N.O., Sheehan, T.P. \& Andrle, V.A.S. 1999. Spore-pollen biostratigraphy and paleoecology of Mesozoic and lower Tertiary samples from the Surghar and Salt Ranges, Northern Pakistan. United States Geological Survey Bulletin, 2078D.

Funnel, B.M. 1967. Foraminifera and Radiolaria as Depth Indicators in the Marine Environment. Marine Geology, 5: 333-347.

Galeotti, S. 1998. Planktic and benthic foraminiferal distribution patterns as a response to changes in surface fertility and ocean circulation: a case study from the late Albian 'Amadeus Segment' (Central Italy). Journal of Micropalaeontology, 17(1): 87-96.

Germeraad, J.H., Hopping, C.A. \& Muller, J. 1968. Palynology of Tertiary sediments from tropical areas. Review of Palaeobotany and Palynology, 6(3-4): 189-348.

Gibson, T. 1989. Planktonic benthonic foraminifera ratios: Modern patterns and Tertiary applicability. Marine Micropalaeontology, 15: 29-52.

Gradstein, F.M., Agterberg, F.P., Ogg, J.G., Hardenbol, J., Van Veen, P., Thierry, J. \& Huang, Z. 1995. A Triassic, Jurassic and Cretaceous time scale. In: Berggren, W.A., Kent, D.V., Aubry, M.P. \& Hardenbol, J. (Eds), Geochronology, Time Scales and Global Correlations. Society of Economic Paleontologists and Mineralogists, Special Publications, 54: 95-126.

Hallock, P.A. 1987. Fluctuations in the trophic resource continuum: A factor in global diversity cycles? Paleoceanography, 2: 457-471.

Haq, B.U., Hardenbol, J. \& Vail, P.R. 1987. Chronology of fluctuating sea-levels since the Triassic. Science, 235: 1153-1165.

Harland, R. 1973. Dinoflagellate cysts and acritarchs from the Bearpaw Formation (Upper Campanian) of Southern Alberta, Canada. Palaeontology, 16: 665-706.

Hart, M.B. 1980. A water depth model for the Evolution of the Planktonic Foraminifera. Nature, 286: 252-254.

Hart, M.B. \& Bailey, H.W. 1979. The distribution of planktonic foraminiferida in the Mid-Cretaceous of NW Europe. In: Weidmann, J. (Ed.), Aspeckte der Kreide Europas. International Union of Geological Sciences, Series A, 6: 527-542.

Hayward, B.W. 1986. Abundant planktic foraminifera in intertidal sediments, Kawerua, Northland. Tane, 31: 1-12.

Hemphill, W.R. \& Kidwai, A.H. 1973. Stratigraphy of the Bannu and Dera Ismail Khan areas, Pakistan. United States Geological Survey, Professional Paper, 716-B: 1-36.

Iqbal, H., Yasin, A.R., Bokhari, N.H., Ashraf, M. \& Nadeem, A. 1994. Sui Main Limestone - its reservoir, isopach, sedimentary and basinal models, Loti area, Central Pakistan. Pakistan Journal of Petroleum Technology, 3: 1-11. 
Jones, R.W. 1997. Aspects of the Cenozoic stratigraphy of the Northern Sulaiman Ranges, Pakistan. Journal of Micropalaeontology, 16: 51-58.

Kemal, A., Balkwill, H.R. \& Stoakes, F.A. 1992. Indus basin hydrocarbon plays. In: Ahmad, G., Kemal, A., Zaman, A.S.H. \& Humayon, M. (Eds), New Directions and strategies for accelerating petroleum exploration and production in Pakistan. Oil and Gas Development Corporation, Islamabad, 78-105.

Kothe, A. 1990. Paleogene dinoflagellates from Northwest Germany: biostratigraphy and paleoenvironments. Geologisches Jahrbuch, 118: 3-111.

Leckie, R.M. 1987. Paleoecology of mid-Cretaceous planktonic foraminifera: A comparison of open ocean and epicontinental sea assemblages. Micropaleontology, 33: 164-176.

Leckie, R.M. 1989. A paleoceanographic model for the early evolutionary history of planktonic foraminifera. Palaeogeography, Palaeoclimatology, Palaeoecology, 73: 107-138.

Leckie, R.M., Schmidt, M.G., Finkelstein, D. \& Yuretich, R. 1991. Paleoceanographic and paleoclimatic interpretations of the Mancos Shale (Upper Cretaceous), Black Mesa Basin, Arizona. In: Nations, J.D. \& Eaton, J.G. (Eds), Stratigraphy, Depositional Environments and Sedimentary Tectonics of the Western Margin, Cretaceous Western Interior Seaway. Geological Society of America, Special Paper, 260: 139-152.

Leckie, R.M., Yuretich, R., West, O.L.O., Finkelstein, D. \& Schmidt, M.G. 1998. Paleoceanography of the southwestern Western Interior Sea during the time of the Cenomanian-Turonian Boundary (Late Cretaceous). In: Dean, W.E. \& Arthur, M.A. (Eds), Stratigraphy and Paleoenvironments of the Cretaceous Western Interior Seaway, USA. Society of Economic Paleontologists and Mineralogists, Concepts in Sedimentology and Paleontology, 6: 101-126.

Loutit, T.S., Hardenbol, J., Vail, P.R. \& Baum, G.R. 1988. Condensed sections: The key to age determination and correlation of continental margin sequences. In: Wilgus, C.K., Posamentier, H.W., Ross, C.A. \& Kendall, G.C.St.C. (Eds), Sea-level Changes: An Integrated Approach. Society of Economic Paleontologists and Mineralogists, Special Publication, 42: 183-213.

Mao, Shaozhi \& Mohr, B. 1992. Late Cretaceous dinoflagellate cysts (?Santonian-Maestrichtian) from the southern Indian Ocean (Hole 748c). In: Wise, S.W. Jr \& Schlich, R. (Eds), Ocean Drilling Program, Proceedings, Scientific Results, 120: 301-347.

Mitchum, R.M., Sangree, J.B., Vail, P.R. \& Wornardt, W.W. 1993. Recognizing sequences and systems tracts from well logs, seismic data, and biostratigraphy: Examples from the Late Cenozoic of the Gulf of Mexico. In: Weimer, P. \& Posamentier, H.W. (Eds), Siliciclastic Sequence Stratigraphy - Recent Developments and Applications. American Association of Petroleum Geologists, Memoir, 58: 163-197.

Morley, R.J. 1991. Tertiary stratigraphic palynology in Southeast Asia: Current status and new directions. Geological Society of Malaysia, Bulletin, 28: 1-36.

Morley, R.J. 1996. Biostratigraphic characterisation of systems tracts in Tertiary sedimentary basins. In: Caughey, C.A., Carter, D.C., Clure, J., Gresko, M.J., Lowry, P., Park, R.K. \& Wonders, A. (Eds), Proceedings of the International Symposium on Sequence Stratigraphy in SE Asia. Indonesian Petroleum Association.

Neal, J.E., Stein, J.A. \& Gamber, J.H. 1994. Graphic correlation and sequence stratigraphy in the Palaeogene of NW Europe. Journal of Micropalaeontology, 13: 55-80.

Neal, J.E., Stein, J.A. \& Gamber, J.H. 1995. Integration of the graphic correlation methodology in a sequence stratigraphic study: Examples from the North Sea Paleogene Sections. In: Mann, K.O. \& Lane, H.R. (Eds), Graphic Correlation. Society of Economic Paleontologists and Mineralogists Special Publication, 53: 95-113.
Nyong, E.E. \& Olsson, R.K. 1984. A paleoslope model of Campanian to Lower Maestrichtian foraminifera in the North American basin and adjacent continental margin. Marine Micropalaeontology, 8: 437-477.

Olsson, R.K. 1988. Foraminiferal modeling of sea-level change in the late Cretaceous of New Jersey. In: Wilgus, C.K., Hastings, B.S., Kendall, C.G.St.C., Posamentier, H.W., Ross, C.A. \& Van Wagoner, J.C. (Eds), Sea-level Changes: An Integrated Approach. Society of Economic Paleontologists and Mineralogists, Special Publications, 42: 289-297.

Olsson, R.K. \& Nyong, E.E. 1984. A paleoslope model for CampanianLower Maestrichtian foraminifera of New Jersey and Delaware. Journal of Foraminiferal Research, 14(1): 50-68.

Picou, E.B., Perkins, B.F., Rosen, N.C. \& Nault, M.J. 1999. Gulf of Mexico Basin stratigraphic index microfossils. A geoscientists guide: Foraminifers and nannofossils, Parts I and II. Gulf Coast Section, Society of Economic Paleontologists and Mineralogists. 215 data sheets, 3 charts, 2 tables of synonyms.

Plaziat, J-C. 1995. Modern and fossil mangroves and mangals: Their climatic and biogeographic variability. In: Bosence, D.W.J. \& Allison, P.A. (Eds), Marine Palaeoenvironmental Analysis from Fossils. Geological Society, London, Special Publications, 83: 73-96.

Posamentier, H.W., Jervey, M.T. \& Vail, P.R. 1988. Eustatic controls on clastic deposition I - conceptual framework. In: Wilgus, C.K. Hastings, B.S., Kendall, C.G.St.C., Posamentier, H.W., Ross, C.A. \& Van Wagoner, J.C. (Eds), Sea-level Changes: An Integrated Approach. Society of Economic Paleontologists and Mineralogists, Special Publication, 42: 109-124.

Poumot, C. 1989. Palynological evidence for eustatic events in the tropical Neogene. Bulletin Centres Recherches Exploration \& Production. Elf-Aquitaine, 13(2): 437-453.

Powell, A.J., Lewis, J. \& Dodge, J.D. 1992. The palynological expressions of post-Paleogene upwelling: a review. In: Summerhayes, C.P., Prell, W.L. \& Emeis, K.C. (Eds), Upwelling systems: evolution since the Early Miocene. Geological Society, London, Special Publications, 64: 215-226.

Quadri, V-U-N. \& Shuaib, S.M. 1986. Hydrocarbon prospects of Southern Indus Basin, Pakistan. American Association of Petroleum Geologists, Bulletin., 70(6): 730-747.

Shaffer, B.L. 1987. The potential of calcareous nannofossils for recognizing Plio-Pleistocene climatic cycles and sequence boundaries on the shelf. Innovative Biostratigraphic Approaches to Sequence Analysis: New Exploration Opportunities. Gulf Coast Section Society of Economic Paleontologists and Mineralogists, Eighth Annual Research Conference: 142-145.

Shafique, N.A. \& Daniels, C.H.v. 1990. Foraminiferal zonation of Upper Goru Formation - Bawani area, Kirthar Range. Pakistan Journal of Hydrocarbon Research, 2(2): 67-84.

Sharland, P.R., Archer, R. \& Casey, D.M. 2001. Arabian Plate Sequence Statigraphy. GeoArabia Special Publication, 2: 1-317.

Simmons, M.D. \& Williams, C.L. 1992. Sequence stratigraphy and eustatic sea-level change: The role of micropalaeontology. Journal of Micropalaeontology, 11: 112.

Smayda, T.J. 1983. The phytoplankton of estuaries, in estuaries and enclosed sea. In: Ketchum, B.H. (Ed.), Ecosystems of the World, 26. Elsevier, Amsterdam, 65-102.

Stover, L.E. \& Williams, G.L. 1982. Dinoflagellates. Third North American Paleontological Convention, Proceedings, 2: 525-533.

Tyson, R. 1995. Sedimentary Organic Matter. Organic facies and palynofacies. Chapman \& Hall, London, 1-615.

Williams, M.D. 1959. Stratigraphy of the Lower Indus Basin, West Pakistan. section 1, paper 19. Proceedings of the 5th World Petroleum Congress, New York: 377-394. 